\title{
HARMONIZATION OF ASEAN INVESTMENT LAWS: ANY POSSIBILITY TOWARD RECOGNITION AND ENFORCEMENT OF FOREIGN JUDGMENTS IN ASEAN MEMBER STATES
}

\author{
Dr. U-Krisdh Musicpunth ${ }^{1}$ \\ Assist. Prof. Anon Sriboonroj ${ }^{2}$ \\ Faculty of Law, Thaksin University, Thailand \\ ${ }^{1}$ E-mail: ukrisdh@gmail.com \\ ${ }^{2}$ E-mail : themis.lawtu@gmail.com
}

\begin{abstract}
In having ASEAN investment related agreements responded to economic activities seeking by investor and service providers or suppliers practically, harmonization of investment related laws among AMS is from time to time reiterated "necessarily needed in various aspects". Since establishment to operation and dispute settlement are under the concept of ASEAN free movement, the host country normally shapes up all processes of doing business by its domestic laws and regulations. Of course, they are depended on each member state's regime and jurisdiction which always different from each other and in principle not apply cross borders. The ten members we already have with sovereignty issue in addition, these make the need of integrity of laws moved even harder. Recommended by the authors as an optional choice, recognition and enforcement of foreign judgments, inter-alia, can play its role as a supportive mechanism under harmonization of investment laws. The legal relationship between investors and investors, investors and states or between states and states in AMS then will be undertaken regionally and seamlessly.
\end{abstract}

Keywords: Harmonization, ASEAN, Investment, Foreign Judgments.

\section{Introduction}

Since formation of former investment agreements, namely the ASEAN Agreement for the Promotion and Protection of Investments or ASEAN Investment Guarantee Agreement (AIGA) and the Framework Agreement on the ASEAN Investment Area (AIA), done in 1987 and 1998 respectively to the conclusion of prevailed investment based agreements applied presently, the ASEAN Framework
Agreement on Services (AFAS) in 1995 and the ASEAN Comprehensive Investment Agreement (ACIA) in 2009, ASEAN member states (AMS) have kept highlighting and repeating the important of economic cooperation and integrity in this region. ${ }^{1}$ The expression of this concept also obviously found along the way in the ASEAN Charter and the ASEAN Economic Community

\footnotetext{
1 Preamble, AIGA; Preamble of AIA; Preamble of ACIA and Preamble of AFAS.
} 
Blueprint. $^{2}$ The Charter, designed as aASEAN constitution, grounds the fundamental principles to drive the move of ASEAN in a single character. The legal basis of the single market ${ }^{3}$ is inscribed thereof whereas the Blueprint has an important function as the master and action plan for establishment of ASEAN Economic Community (AEC) with the aim to have them followed and implemented by all ASEAN Member States (AMS). ${ }^{4}$

In order to implement economic integration in ASEAN region practically, suggested by Lawan Thanadsillapakul, the regional laws and institutions to supporting and strengthening are needed. ${ }^{5}$ Again, her suggestion recently mentioned in an academic article by Huda, Nugraheni, and Kamarudin. ${ }^{6}$ In terms of laws, Rajagukguk recognized the relation between effective legal framework and economic development and the harmonization of laws in economic circle is possible. Said, a solid legal framework is a basic element to economic integration. The issues of laws in need are both domestic and

\footnotetext{
${ }^{2}$ Para 2 (Introduction), para 5 (Characteristics and Element of AEC) for example.

${ }^{3}$ Article 1.5, ASEAN Charter.

${ }^{4}$ Art. 2, ASEAN Charter.

${ }^{5}$ Thanadsillapakul, Lawan. (2004). The Harmonisation of ASEAN Competition Laws and Policy and Economic Integration. Uniform Law Review - Revue de droit uniforme. 9. 10.1093/ulr/9.3.479. p 4.

${ }^{6}$ Huda, Mokhamad \& Nugraheni, Ninis. (2016). Harmonizing Competition Law in the ASEAN Economic Community. International Journal of Business, Economics and Law. 9. P. 51.
}

international to reflex the cross- borders trade and investment. Namely, the law of contract, law of corporation, law of finance, law of intellectual and property right, law of arbitration and so on are for domestic dimension whereas the law of tariff, protection of investment and investor, dispute settlement and ISDS, etc. for international aspect. He also proposed that a further need is apparatus to implement those laws and regulation. It is a role of court. The court can serve its important role in dispute 'settlement and arbitration processes. ${ }^{7}$

However, issues of concern in came across in conduction of literature review. The different of regimes belong to each AMS. The common law system of three AMS (Malaysia, Singapore and Brunei) and other four are under the civil law system. They are convergent but divergent in a while. ${ }^{8}$ Recourse of approaches, conditions, and efforts required for a single country may be different from other ones even for the same goal. ${ }^{9}$ Unlike the practices done by European

7 Erman Rajagukguk, Harmonization of Law in ASEAN Countries towards Economic integration 9 Indonesian J. Int'l L. 529 (2011-2012), p. 530, 531, 532, 537; in his view, the legal framework must be with quality of stability, predictability and fairness, and the legal certainty is important basis together with economic opportunity, political stability and investment incentive.

${ }^{8}$ Ibid, p. 532.

9 . Critical Issues of Investment Law Harmonization within ASEAN from Viet Nam Perspective, speech by Nguyen Tien Lap, Senior partners of NHQuang \& Association, at ALA Workshop, Bali, February, 14-19, 2012, from ASEAN law Association database: 
Union (EU) members, AMS typically have reserved their sovereignty right and hardly share with any institution. ${ }^{10}$ Harmonization in AEC framework, there are no legal provisions with international binding all $\mathrm{AMS}^{11}$, not even a model law provided to guide or shape them up all along the line.

Further, the Charter and other investment related agreements mentioned above have not established any supranational authorities to govern the member states. In ASEAN, we do not have the ASEAN Parliament, ASEAN Court and ASEAN Commission as yet existed in European Union (EU). We also do not have any strong tradition of judicial cooperation to gear up and drive our harmonization process as pointed out by Peerapan Tungsuwane. ${ }^{12}$ Moreover, as seen through a free trade agreement concluded with non-ASEAN country, each AMS normally focus mainly on her own instead of a single benefit as a whole. $^{13}$

In this paper, Arnon and I would like to express our idea on the recognition and enforcement of one AMS judgment in other AMS territories. We do propose this idea as

https://www.aseanlawassociation.org/11GAdocs/wor kshop3-viet.pdf.

10 Tungsuwane, Peerapan, Critical Issues on Investment Law Harmonization within ASEAN, p. 2, from ASEAN law Association database: https://www.aseanlawassociation.org/11GAdocs/work shop3-thailand.pdf

${ }^{11}$ Ibid. p. 1.

12 Ibid. p. 3.

${ }^{13}$ Ibid. p. 4. an alternative option working in parallel path or initial proposal for a further research deeply in the issue.

In our understanding, we believe that movement of judgments among AMS will underpin, at least, a basic structure of ASEAN legal harmonization along with any other mechanisms proposed. Our narration of contents, based on revision of Arnon's $\operatorname{articles}^{14}$ introduced recently, his summary ideas divided into the three main parts. The first part touches upon the current form of recognition and enforcement of foreign judgments in AMS, following by the rules and methods of AMS in doing so, and ends up with the obstacles and difficulties of those to implement among them.

\section{Results and Analysis}

\section{Form of recognition and enforcement of} foreign judgments in AMS

A state, in former time, had enjoyed its sovereignty right in ways of legislation, administration and judiciary which is that enjoyment not subject to any other sovereignty. Namely, enjoyment of one's sovereignty cannot be harmful to other one's or par in parem imperium non habet. Anyway, the development of economic transactions where goods,

14 อานนท ศรบุญโรจน,
การรบรองและการบงคบตามคาพพากษาศาลตางประเ ทศในกลมประเทศอาเซยน,

วารสารบณฑตศกษานตศาสตร, ปท : 4 ฉบบท $: 3$ เลขหนา 238-245 ปี พ.ศ. : 2554 (available only in Thai version). 
services and investment moving across ones territories has brought those rigid rights declined. From the principle of territorial sovereignty that judgments can only be enforced within its jurisdiction, there a tendency of judgments movement recognized and effected outside their own lands.

The recognition and enforcement of foreign judgments has paid important role as to serve the change and expansion of economic activities. In modern world, the relationship between state to state, state to individual and individual to individual is not limited within a single country. The cross borders based relation is obviously seen in almost forms of business, trades and investments, particularly in areas where free trade is established.

In ASEAN economic context, recognition and enforcement of foreign judgments, according to Vitit Muntarporn, it move rather slowly ${ }^{15}$ even though the regional legal consistency was mentioned since the foundation of its Association in 1967

\footnotetext{
15 วทต มนตาภรณ, "ความรวมมอทางศาลเกยวกบการบงคบตามคาพพา กษาตางประเทศแงคดแนวอาเซยน", ดุลพาห, เลม 2 ปท 31 , (มนาคม-เมษายน 2527), p. 89. (available only in Thai version) cited in อานนท ศรบุญโรจน, การรบรองและการบงคบตามคาพพากษาศาลตางประ เทศในกลมประเทศอาเซยน, วารสารบณฑตศกษานตศาสตร, ปีท : 4 ฉบบท :3 เลขหนา 238-245 ปี พ.ศ. : 2554.
}

\subsection{Justice co-operation between AMS in} civil and commercial laws

Based on the 1967 Bangkok Declaration and the 1976 Declaration of ASEAN Concord, the legal consistency was first introduced in 1984 and led to the AMS Laws co- operation forum. They also have common view to develop and improve the harmonization of regional laws along the line. In 1967 Declaration, clearly stated that. ${ }^{16}$

"...the aims and purposes of the Association shall be...To promote regional peace and stability through abiding respect for justice and the rule of law in the relationship among countries of the region and adherence to the principles of the United Nations Charter..."

In 1986, ASEAN declared the legal co-operation between members in ASEAN Ministerial Understanding on The Organizational Arrangement for Cooperation in the Legal Field focusing on exchange of legal information and document, judiciary co- operation, and legal research. Nothing in regional level touched upon recognition of members' judgments ever since. The cooperation, however, was concluded among few members whose historical backgrounds were shared. ${ }^{17}$ Under the Reciprocal Enforcement of

\footnotetext{
16 https://asean.org/the-asean-declaration-bangkokdeclaration-bangkok-8-august-1967

${ }^{17}$ Supra note, วทต มนตาภรณ, p. 91-92. Referred to Malaysia, Singapore and Brunei who were colonized by the British.
} 
Commonwealth Judgments $\mathrm{Act}^{18}$ of Singapore where the judgments issued by the British Superior Court and registered in Singapore are enforceable. ${ }^{19}$ The law also extends onto the judgments of Superior Court of any other countries, including Malaysia and Brunei, based on treatment of reciprocity. ${ }^{20}$

\subsection{Source of laws on recognition and} enforcement of foreign judgments in AMS

According to his article, Arnon divided the origin of laws in ASEAN states on this matter into 2 main sources; written and non-written law.

The written law on recognition and enforcement of foreign judgments is widespread and promulgated in many member states' domestic regime excepted Thailand and Indonesia. Some - the Philippines and CLMV members - specify it in the law of procedure and others Malaysia, Singapore and Brunei - place it

18 the Reciprocal Enforcement of Commonwealth Judgments Act 1921 (revised edition 1985, available in https://sso.agc.gov.sg /Act/RECJA1921.

19 Title 3.1, the Reciprocal Enforcement of Commonwealth Judgments Act.

20 Title 5.1, the Reciprocal Enforcement of Commonwealth Judgments Act, and please see also จนตร สนศภฤกษ, "การ. ยอมรบและบงคบตามคาพพากษาศาลตางประเทศ," (วทยานพนธมหาบณฑต คณะนตศาสตร มหาวทยาลยจฬ์ลงกรณ, 2531), p. 175. (available only in Thai version) cited in อานนท ศรบุญโรจน, การรบรองและการบงคบตามคาพพากษาศาลตางประ เทศในกลมประเทศอาเซยน,

วารสารบณฑตศกษานตศาสตร, ปท: 4 ฉบบท :3 เลขหนา $238-245$ ปี พ.ศ. : 2554. in a specific law (lex specialis). The law in a form of treaty, on the other hand, is not under their attention regardless of how long the arrangement of relevant convention has been proposed. ${ }^{21}$

The non-written law, the recognition and enforcement of foreign judgments in some AMS can be created by judgments of domestic courts, particularly in Malaysia, Singapore and Brunei that British Common Law has direct impact upon.

2. Rules and Methods of AMS in recognition and enforcement of foreign judgments

Apart from the principle of reciprocity, some AMS -Malaysia, Singapore and Brunei- also have adopted the principle of obligation theory. When judgments issued by a country with statutory system requested, the reciprocity will serve. The obligation theory will apply in case the judgments made under Common Law system.

In the case of Indonesia, the principle of territorial sovereignty is strictly observed. The Philippines also embraces this principle but leaves more

${ }^{21}$ Supra note, วทต มนตาภรณ, p. 88-104, please see also Pearlie M.C. Koh, "Foreign Judgments in ASEAN: A Proposal," The International and Comparative Law Quarterly, Vol. 45, No. 4 (Oct., 1996), pp. 844-860, และในการ ประชุม ASEAN Law Forum ครงท 3 ระหวางวนท 11-13 กนยายน พ.ศ. 2549 (ค.ศ. 2006) ทจงหวดหนองคาย ใน Panel Discussion: Session 6. 
rooms to play. For Thailand, the recognition and enforcement of foreign judgments is on the comity of nations basis.

2.1 Approaches of recognition and enforcement of foreign judgments

Some AMS, both civil or common laws backgrounds, have foreign judgments adopted into their jurisdiction via a domestic litigation process. The foreign judgments will be used as an evidence or ground for examination process. For AMS with common law background, they have more flexible room to import those judgments as mentioned earlier. Through the domestic litigation process for a judgment from any common law country and the registration process for one from statutory system. The latter case, a foreign judgment will be effectively enforced in equivalent to an inhouse one.

In the case of Indonesia and Thailand, a foreign judgment is recognized just as prima facie evidence. The enforcement, consequently, can be settled with recourse to "trial de novo" a new litigation.

2.2 Court jurisdiction and authority of court

It is common understanding, the only issue perhaps, among all AMS that a foreign judgment must be issued by a competent court of rendering and carried out by a competent court of enforcing. Some AMS adopt a foreign judgment without any reservation of revision au fond authority; an enforcing court can never make any changes of that judgment. Unlike the Philippines, the court has right to form a hearing procedure and to have the merit of judgment revised in the case any errors of factual or legal question found.

\subsection{Finality of foreign judgments}

The finality of judgment is, inter alia, a controversial issue among member states. Some, common and civil laws states, have agreed that only judgment with the finality and conclusiveness is permissible. However, some civil law states have shared their views on the finality status only if it became final and sanction from any higher court impermissible. While the common law states have a different view, a foreign judgment issued by a competent court is final and enforceable and regardless of any further process - right to appeal for example - if there are.

3. Obstacles and difficulties of implementation

Refer to his survey on this issue, Arnon has found some barriers in implementing of recognition and enforcement of foreign judgments in ASEAN umbrella. His article gives 
readers informative view into two points as I could summarize as follows;

\subsection{Concept of sovereignty}

The sovereignty, in one way or another, plays a crucial role and becomes a protective wall against the idea of recognition and enforcement of foreign judgments among AMS. In one understanding, permission of foreign judgment enforced inbound is integrity loss of its sovereignty. Further, the normative practice of ASEAN, their priority approach is non-intervention and non-interference. ${ }^{22}$

\subsection{Regime of laws}

As mentioned above, there are different legal systems and regimes in member states of ASEAN. This brought the inconsistency of legal system and barred the co-operation of AMS to have an idea of recognition and enforcement of foreign judgments implemented cross the board effectively.

\section{Conclusion}

Harmonization of investment related laws in ASEAN region needs the serious attention of AMS. The laws of region to contribute and accelerate investment and any other trade issues require new legislation, new mechanisms and changes. Yes, the regional harmonization of law itself may be a right answer to this matter. Anyway, there

\footnotetext{
${ }^{22}$ Supra note, Tungsuwane, Peerapan, p. 3.
}

are several limitations to break through. The multi speeds of economic development, differences of regime, proper governing and monitoring mechanism and so on including national based benefits are for example. The critical question thereof for them is "what the most appropriate methodology for ASEAN to drive the legal harmonization implemented practically?"

On the back door approach, the idea of recognition and enforcement of foreign judgments between one AMS to another AMS is suggested. It might not be the direct way to create harmonization per se. the cooperation of AMS courts and free movement of their judgments with ASEAN territory could help forming a basis of legal integration. It is an optional method proposed that should be taken into account and carried out side by side with the direct harmonization.

However, the strong and rigid concept of sovereignty in economic world, together with different legal regimes, can be one of prominent obstacles to move forward the ASEAN vision on economic goal. The concept of free trade and single market of ASEAN and its prosperity is depended on AMS to make the right decision for their own future.

\section{References}

Critical Issues of Investment Law Harmonization within ASEAN from Viet Nam Perspective, speech by 
Nguyen Tien Lap, Senior partners of NHQuang \& Association, at ALA Workshop, Bali, February, 14-19, 2012, from ASEAN law Association database:

https://www.aseanlawassociation.org/11 GAdocs/workshop3- viet.pdf

Erman Rajagukguk, Harmonization of Law in ASEAN Countries towards Economic integration 9 Indonesian $\mathrm{J}$. Int'1 L. 529 (2011-2012), p. 531.

Huda, Mokhamad \& Nugraheni, Ninis. (2016). Harmonizing Competition Law in the ASEAN Economic Community. International Journal of Business, Economics and Law. 9.48-53.

Thanadsillapakul, Lawan. (2004). Harmonisation of ASEAN Competition Laws and Policy and Economic Integration. Uniform Law Review Revue de droit uniforme. 9.10.1093/ulr/9.3.479.

Tungsuwane, Peerapan, Critical Issues on Investment Law Harmonization within ASEAN, from ASEAN law Association database: https://www.aseanlawassociation.org/11 GAdocs/workshop3-thailand.pdf

คานนทญโรจน,
การรบรองและการบงคบตามคาพพากษา
ศาลตางประเทศในกลมประเทศอาเซยน,
วารสาร บณฑตศกษานตศาสตร, ปท : 4
ฉบบท :3 เลขหนา $238-245$ ป พ.ศ. :
2554.

